\title{
Environmental regulation in the twenty-first century: a systematic review of (and critical research agenda for) JEPP scholarship
}

\section{Jeroen van der Heijden}

To cite this article: Jeroen van der Heijden (2020): Environmental regulation in the twenty-first century: a systematic review of (and critical research agenda for) JEPP scholarship, Journal of Environmental Policy \& Planning, DOI: 10.1080/1523908X.2020.1767549

To link to this article: https://doi.org/10.1080/1523908X.2020.1767549

\section{曲 Published online: 21 May 2020.}

Submit your article to this journal $\pi$

\section{Llll Article views: 55}

a)

View related articles

View Crossmark data $₫$ 


\title{
Environmental regulation in the twenty-first century: a systematic review of (and critical research agenda for) JEPP scholarship
}

\author{
Jeroen van der Heijden (10, ${ }^{a, b}$

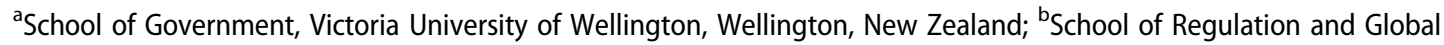 \\ Governance, Australian National University, Canberra, Australia
}

\begin{abstract}
Statutory and other forms of government-led environmental regulation (further 'environmental regulation') have evolved considerably since the mid-twentieth century. However, JEPP scholarship has shown little engagement with these developments over the last two decades. This lack of attention is unwarranted because environmental regulation is still a dominant approach to achieving the goals of environmental policy and planning. This article seeks to map, explore and evaluate current JEPP engagement with environmental regulations; explore three of the major developments in statutory and other forms of government-led regulation over the last decades relevant to environmental policy and planning; and present an environmental regulation research agenda for future JEPP scholarship.
\end{abstract}

\section{KEYWORDS}

Environmental regulation; statutory regulation; regulatory governance; review; research agenda; socio-legal

\section{Introduction}

Since the mid-twentieth Century, a variety of approaches have been used to achieve environmental goals. The most dominant approaches concern the development of property rights, private contracts, and self-regulation by private parties, subsides - when governments have authority the delivery of goods and services through public ownership - and other forms of government-led environmental regulation and statutes (Daniels, 2014; Falkner, 2013). Of these, the latter is dominant in many areas of environmental policy and planning around the world. Strikingly, over the last two decades, JEPP scholarship has engaged very little with government-led environmental regulation (further 'environmental regulation') and statues. This article calls for more engagement with this (perhaps less fashionable but widespread and potentially impactful) form of environmental policy and planning in future JEPP scholarship.

Throughout this article, I mainly engage with the implementation, monitoring and enforcement of regulation from a socio-legal scholarship perspective. As Lo et al. explain in another article in this special issue, environmental regulatory governance has been growing in complexity over the last decades. The regulatory literature has followed suit and has grown in size and complexity in its attempts to map, explore and interrogate environmental regulation. As such, this article is best understood as providing a snapshot of 'regulatory delivery' (Russell \& Hodges, 2019) taken through the lens of socio-legal regulatory scholarship. This snapshot engages less, for example, with insights on regulation from the law and policy scholarship, the economics of regulation scholarship or the politics of regulation scholarship (e.g. Balleisen \& Moss, 2012; Decker, 2015; Dudley \& Brito, 2012; Kahn, 1988; Viscusi et al., 2005).

In socio-legal scholarship, environmental regulation is generally conceptualised as 'sustained and focused control exercised by a public agency over activities that are valued by a community' (Scott, 2012, p. 18). The goals of environmental regulation and legislation overlap, but there are essential differences. Environmental regulation 'predominantly functions as a market intervention aiming for a correction,' whereas environmental 
legislation serves broader functions, including institutional and symbolic ones (Voermans, 2016, p. 23). Environmental regulation is used by governments to influence the environmental behaviour of individuals and collectives; to make predictable social interaction and transactions as they relate to environmental goals; and to reduce environmental harms and risks by setting expectations (ie. rules) and consequences for failing to comply (ie. rewards and penalties) (Lodge \& Wegrich, 2012; P. May, 2007; McCraw, 1984). Central to environmental regulation is that it is backed by the force of law, meaning that non-compliance may be treated as a criminal offence (Bourdieu, 1987; Parker et al., 2005). In short, environmental regulation seeks to achieve pro-environmental behaviour in individuals and organisations. In this article, environmental regulation is considered an instrument of and approach to environmental governance, policy and planning (thus, it is a subset of the latter) (Baldwin et al., 2012; Levi-Faur, 2011).

Environmental regulation saw a rapid growth in the twentieth century. For example, by the late 1960s, the United States Congress determined that the tort regime 'was incapable of providing an effective response to the increasing threats to the public health and safety and the environment attributable to new technologies and development' (Shapiro \& Glicksman, 2003, p. 3). Between the 1960s and the 1990s, this led to a move in the United States away from minimal government intervention in regulating environmental objectives towards an approach in which the government often took pre-emptive action to regulate anticipated environmental harms and risks (Dudley \& Brito, 2012). In the 1970s, countries in Europe followed suit and, eventually, environmental regulation spread further around the globe (Hood et al., 2001; Majone, 2016; D. Vogel, 2012).

Nevertheless, since the 1980s, this approach to regulation began to face criticism. Critics state that government-led environmental regulation is ineffective and expensive; that it brings about problems with enforcement; and that it aims too much at downstream solutions (Fairman \& Yapp, 2005). It is also accused of being prone to regulatory capture when the relationship between the regulator and its subject becomes too close (Van der Heijden, 2017). Furthermore, environmental regulation might be hijacked by legislative legalism where the proliferation of rules leads to over-regulation, strangling competition and entrepreneurship in the marketplace (Bardach \& Kagan, 1982). Subsequently, the setting of standards is difficult since public goals often cannot be expressed in technical terms, and the enforcement of regulations might be difficult or expensive due to overly complex rules, as is evident in increased compliance costs for those subject to regulation (Baldwin et al., 2012).

Understanding these shortcomings and responding to societies' calls for regulatory reform, governments around the globe have been actively exprimenting with regulation since the 1980s (Gunningham, 2009; Jordan et al., 2003, 2005, 2013). These include the privatisation of regulatory enforcement, a reliance on industry selfregulation, and a move away from policy instruments that penalise violations towards instruments that reward compliance. However, none of their innovations to-date have substantially changed environmental regulation, let alone replaced it. Around the globe, government-led environmental regulation is still a dominant market intervention, building on pre-defined standards and backed by the force of law (Blackman et al., 2018; Braathen, 2019; Bulkeley et al., 2013; Percival et al., 2018). Therefore, environmental regulation is still vital to many of the areas that are of central concern in JEPP.

Given the prominence of regulation in the real-world practice of environmental policy and planning, the next section seeks to understand whether, how, and with what results JEPP scholarship has engaged with statutory and other forms of government-led environmental regulation, as well as the broader debates on regulation in socio-legal scholarship. Because the systematic review indicated limited engagement with these topics, the section that follows explores how regulatory scholarship and the broader regulatory literature can inform future debates on environmental regulation in JEPP. Finally, the article concludes with a research agenda of pressing regulatory challenges for JEPP scholarship.

\section{Environmental regulation and regulatory scholarship in JEPP}

To understand whether, how, and with what results JEPP has engaged with debates on regulation and the sociolegal regulatory literature more generally, a systematic review was conducted of all 556 regular articles published in JEPP between 1999 and 2019, ${ }^{1}$ as well as all 16 regular editorials to JEPP. ${ }^{2}$ The systematic review followed 
standard practice for this type of review, both for the collection of sources and their analysis (Bearfield \& Eller, 2008; Sutton et al., 2016). Publications in this review section were sourced through the search function on the JEPP website (https://www.tandfonline.com/loi/cjoe20). All publications identified have been analysed in full.

\section{Classification of JEPP scholarship as 'regulatory' by authors}

The JEPP database was first explored for articles using keywords that indicate a 'regulatory' focus. Keywords give a good indication of the areas of research or scholarly debates to which authors seek to relate their work. The keywords included in the search reflect the conceptualisation of environmental regulation discussed in the introduction to this article: an attempt to change behaviour through the setting of standards, monitoring of compliance with these standards, and the enforcement of non-compliance. The main search terms is 'reg-

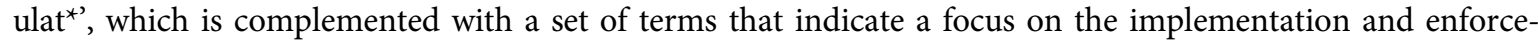
ment of regulation: 'compliance', 'enforc', 'behaviour OR behave ${ }^{\star}$. Here the '^' operates as a wildcard, indicating that the term 'regulat*' includes terms such as 'regulation', 'regulations', 'regulator', 'regulating', and so on $^{3}$; the OR functions as the logical 'or', and the AND functions as the logical 'and'. The JEPP database was explored further for the use of the same 'regulatory' terms in the titles of articles. Again, titles are a good indicator of how authors want to position their work in the broader body of scholarship. Table 1 provides an overview of findings.

Table 1 indicates that scholars publishing in JEPP do not often consider, or brand, their work as having a 'regulatory' focus. For example, terms indicating that an article addresses regulation, regulators, or another regulatory topic ('regulat') were traced in 14 articles and in titles of nine (9) articles. These terms were used as either the keywords or in the titles of 19 articles. After removing overlap in the use of 'regulatory' terms in the titles across articles, a total of 21 unique articles remained that used a term indicating a possible regulatory focus in its keywords or title. ${ }^{4}$

\section{Use of concepts central to regulatory literature in JEPP scholarship}

Having gained an understanding of how scholars classify their own JEPP articles, the analysis turned to the use of concepts central to the regulatory literature in JEPP scholarship. To do so, 15 core regulatory concepts were explored: 'regulatory governance', 'regulatory regime,' 'regulatory system,' 'regulatory reform,' 'regulatory enforcement,' 'regulatory science,' 'regulatory state,' 'risk regulation,' 'better regulation,' 'behavio${ }^{\star}{ }^{\star}$ regulation,' 'economic regulation,' 'social regulation,' 'private regulation,' 'public regulation,' and 'regulatory compliance.' Again, the ' $*$ ' operates as a wildcard. Table 2 gives an overview of the findings.

Table 2 lists engagement in JEPP either with concepts central to socio-legal regulatory scholarship or the key-debates in the socio-legal regulatory literature (e.g. Baldwin et al., 2012; Drahos, 2017; Levi-Faur, 2011; Morgan \& Yeung, 2007; Parker et al., 2005). The most common concepts traced in JEPP articles are 'regulatory system' (in 17 articles), 'regulatory regime' (in 15 articles), and 'public regulation' (in nine articles). However, often these concepts are mentioned only once in JEPP articles, indicating that authors use the terminology of the concept in passing, rather than actively engage with the concept. For example, the three most common concepts traced were used more than once in three, four and two articles respectively. This finding of limited engagement is underlined further by the insight that concepts central to the

Table 1. Classification of JEPP scholarship as 'regulatory' by authors.

\begin{tabular}{lccc}
\hline Term & $\begin{array}{c}\text { Mentioned as keyword on } n \text { JEPP } \\
\text { article(s) }\end{array}$ & $\begin{array}{c}\text { Mentioned in title on } n \text { JEPP } \\
\text { article(s) }\end{array}$ & $\begin{array}{c}\text { Mentioned as keyword OR in title on } n \text { JEPP } \\
\text { article(s) }\end{array}$ \\
\hline Regulat* & 14 & 9 & 19 \\
Enforce* & 2 & 1 & 2 \\
$\begin{array}{l}\text { Compliance } \\
\begin{array}{c}\text { Behaviour OR } \\
\text { behave* }\end{array}\end{array}$ & 4 & 3 & 5 \\
\hline
\end{tabular}


Table 2. Use of concepts central to regulatory literature in JEPP scholarship.

\begin{tabular}{lccc}
\hline Concept & Mentioned in $n$ JEPP article(s) & Mentioned $>1$ in those JEPP article(s) & Concept defined in those JEPP article(s) \\
\hline Regulatory governance & 1 & 0 & 0 \\
Regulatory regime & 15 & 3 & 0 \\
Regulatory system & 17 & 4 & 0 \\
Regulatory reform & 4 & 1 & 1 \\
Regulatory enforcement & 1 & 0 & 0 \\
Regulatory science & 5 & 1 & 1 \\
Regulatory state & 3 & 1 & 0 \\
Risk regulation & 6 & 3 & 2 \\
Better regulation & 6 & 1 & 1 \\
Behavio*** regulation & 0 & 0 & 0 \\
Economic regulation & 2 & 1 & 0 \\
Social regulation & 9 & 2 & 0 \\
Private regulation & 7 & 2 & 2 \\
Public regulation & 9 & 2 & 0 \\
Regulatory compliance & 4 & 0 & 0
\end{tabular}

regulatory literature are often not defined or operationalised in JEPP articles. For example, none of the three most common concepts traced before were defined or operationalised in any of the JEPP articles that use them.

\section{Engagement with foundational texts of regulatory literature in JEPP scholarship}

Finally, the database was explored to gain an understanding of whether and how scholars engage with some of the foundational texts in the socio-legal regulatory literature in their JEPP articles. A total of 15 books central to the socio-legal regulatory scholarship were selected from among the most common socio-legal regulatory scholarship handbooks and overviews (e.g. Baldwin et al., 2012; Drahos, 2017; Levi-Faur, 2011; Morgan \& Yeung, 2007; Parker et al., 2005). Table 3 gives an overview of those findings. ${ }^{5}$ Table 3 also reports the total Google Scholar citation count for the period 1999-2019 to indicate the broader impact.

As Table 3 indicates, very few citations of key works in the socio-legal regulatory literature appear in JEPP articles. The only book that received more than five citations over the last two decades of JEPP scholarship is Neil Gunningham and Peter Grabosky's Smart Regulation: Designing Environmental Policy (1998). However, the JEPP authors who cite this book, like the JEPP authors citing any of the other key works, do not actively engage with the content of it. This is illustrative of a broader pattern: When books central to the socio-legal

Table 3. Engagement with foundational texts of regulatory literature in JEPP scholarship.

\begin{tabular}{|c|c|c|c|}
\hline Title & $\begin{array}{l}\text { Scholar.Google } \\
\text { citations }\end{array}$ & $\begin{array}{l}\text { Cited in } n \text { JEPP } \\
\quad \text { article(s) }\end{array}$ & $\begin{array}{l}\text { Engagement with the book in } n \text { JEPP } \\
\text { article(s) }\end{array}$ \\
\hline Responsive Regulation (Ayres \& Braithwaite, 1992) & 4,738 & 2 & 0 \\
\hline Smart Regulation (Gunningham \& Grabosky, 1998) & 1,749 & 6 & 0 \\
\hline Regulatory Craft (Sparrow, 2000) & 749 & 0 & 0 \\
\hline $\begin{array}{l}\text { Understanding Regulation (Baldwin \& Cave, 1999; } \\
\text { Baldwin et al., 2012) }\end{array}$ & 2,995 & 2 & 0 \\
\hline Government of Risk (Hood et al., 2001) & 1,282 & 1 & 0 \\
\hline Nudge (Thaler \& Sunstein, 2009) & 13,280 & 0 & 0 \\
\hline Global Business Regulation (Braithwaite \& Drahos, 2000) & 3,346 & 2 & 0 \\
\hline Going by the Book (Bardach \& Kagan, 1982) & 1,598 & 2 & 0 \\
\hline Street-Level Bureaucracy (Lipsky, 1980) & 15,910 & 4 & 0 \\
\hline Reinventing Government (Osborne \& Gaebler, 1992) & 16,736 & 3 & 0 \\
\hline Politics of Regulation (Jordana \& Levi-Faur, 2004) & 476 & 0 & 0 \\
\hline $\begin{array}{l}\text { Introduction to Law and Regulation (Morgan \& Yeung, } \\
\text { 2007) }\end{array}$ & 410 & 0 & 0 \\
\hline Audit Society (Power, 1999) & 8,880 & 2 & 0 \\
\hline Freer Markets, More Rules (S. K. Vogel, 1996) & 1,706 & 0 & 0 \\
\hline Bureaucracy (Wilson, 1989) & 6,248 & 0 & 0 \\
\hline
\end{tabular}


regulatory literature are cited in JEPP articles they often feature as support for, or as an example of, a general claim rather than a specific regulatory insight.

In sum, over the last two decades, JEPP scholarship has shown remarkably little engagement with statutory and other forms of government-led environmental regulation as means of achieving the goals of environmental policy and planning. JEPP scholarship also shows very little engagement with the broader socio-legal regulatory scholarship and literature. This is not to say that JEPP scholarship has actively ignored regulation as a topic of scholarly enquiry. Non-statutory forms of regulation, such as industry self-regulation, voluntary regulation and regulatory partnerships have featured regularly in its issues (e.g. Bailey, 2008; Carter \& Weible, 2013; Taylor \& Lawrence, 2012). ${ }^{6}$ Arguably, the new environmental policy instruments that have emerged since the 1990s regulatory and other - and the oft-observed shift from government-led environmental policy and planning to environmental governance (Jordan et al., 2003, 2005, 2013; Young et al., 2008), may have drawn JEPP's attention away from studying 'traditional' statutory and other forms of government-led environmental regulation.

\section{Environmental regulation today: innovations in the late-twentieth century and early-twenty- first century}

While the interest in 'new' environmental policy and planning instruments at the expense of studying 'old' environmental regulation is understandable, it is not fully warranted. As indicated earlier, statutory and other forms of government-led environmental regulation are still dominant to achieving the goals of environmental policy and planning in most areas around the world (Blackman et al., 2018; Braathen, 2019; Bulkeley et al., 2013; Percival et al., 2018). Moreover, since the 1960s, this regulation has witnessed considerable changes in response to criticism. Understanding these changes and how they affect the performance of environmental regulation is essential if we wish to develop more effective, efficient, transparent, accountable, and equitable environmental policy and planning. In what follows, three turns in statutory and government-led regulation are discussed as they relate to achieving environmental goals, and therefore are relevant to future JEPP scholarship. While these three turns by no means cover all innovations in regulation that we have witnessed over recent decades, they do give the reader a taste of what 'modern' environmental regulation looks like and how it is discussed in the socio-legal literature - and why it may be of interest for JEPP scholars to explore further. ${ }^{7}$

\section{A pragmatic turn}

Traditionally, regulatory interventions were built on the premise that, in order to be effective, regulation should induce a fear of the consequences of non-compliance (Stigler, 1971). But starting in the late 1970s onward, scholars have pointed out that for environmental regulation in particular this deterrence-based approach comes with a risk. While deterrence-based approaches may avoid environmentally detrimental action in a wide variety of settings, it is, ultimately, occupied with restoring harm done after non-compliance is observed (Gunningham \& Grabosky, 1998; Weiss et al., 2019). The risk is that this 'downstream' solution may result in harms that cannot be easily remedied - for example, when marine life dies from an oil spill; or when global temperatures rise because of increased levels of greenhouse gasses in the atmosphere. In addition, from the 1960s onwards, evidence began to indicate that many people comply with regulations not because they fear the consequences of non-compliance, but because they feel a moral duty to obey (Andrews \& Bonta, 2010; Tyler, 1990). Building on these insights, governments moved away from deterrence-based regulation as a mere 'end of pipe solution' and began using it as a precautionary instrument also (David \& Sinclair-Desgagné, 2005; Mayer et al., 2002).

In addition, governments began trailing compliance-oriented regulations that encourage spontaneous obedience, such as rewarding desired behaviour with positive incentives such as grants or subsidies, to replace traditional deterrence-based regulation (Parker, 2000). Yet, relying solely on compliance-oriented regulation was quickly revealed as having its own shortcomings (Parker, 2000). For example, positive incentives work indirectly, might kick-in too late, and it can be difficult to measure their actual effects on compliance or lack thereof (Baldwin et al., 2012). Also, as is particularly problematic for environmental regulation, public concern 
may arise as to why some harmful behaviour is nevertheless accepted. One such example is regulating the carbon credit trade. Such regulation generally awards tradable credits to those who comply with high environmental standards while penalising those who do not comply by requiring them to buy credits. Here the public may question why those who do not comply can simply 'buy' their way out of non-compliance rather than having to change their behaviour and reduce their carbon emissions (Perdan \& Azapagic, 2011). These combined insights about the strengths and weaknesses of deterrence-oriented and compliance-oriented regulation led to a ground-breaking strategy in the early 1990s: responsive regulation (Ayres \& Braithwaite, 1992). Ayres and Braithwaite's theory builds on the notion that rejecting deterrence-oriented regulation is naïve, while total commitment to it might lead to unnecessary employment of means. They also promote the use of different, less punitive and less restrictive regulation - and preferably a mix of both: 'The trick of successful regulation is to establish a synergy between punishment and persuasion' (Ayres \& Braithwaite, 1992, p. 25). The relationship between regulator and those subject to regulation, and the regulator's ability to choose between different sanctions and rewards to provide tailored solutions to the situation at hand, is regarded the strength of this model (Braithwaite, 2011).

Such pragmatic regulatory approaches may hold considerable promise for environmental regulation (Gunningham \& Grabosky, 1998; Howlett \& del Rio, 2015), particularly in situations where it is difficult to restore environmental harm. In such instances, it may be preferable if the regulator takes a facilitative stance, aiming to support those subject to regulation in achieving compliance, rather than waiting for harm to occur and then penalise the offender. A facilitative stance may involve, for instance, explaining the intent of the rules or exploring different trajectories towards compliance with the regulatory subject (Gunningham, 2002). This is not to say that the regulator should provide (binding) advice. Rather, making optimal use of the discretionary space that frontline regulatory staff have - particularly inspectors - can make all the difference between harm prevention and (costly or sometimes impossible) harm repair (May \& Winter, 1999). This is also not to say that the regulator should always begin with a facilitative stance (Parker, 2013). Imminent environmental harms need a fitting response (e.g. the immediate closure of a factory when illegal toxic waste dumping is observed). Responsive regulation and mixed regulatory approaches allow regulators to move between different interventions while promoting compliance. This approach to, or strategy for, regulation puts more decision-making power in the hands of those who directly engage with regulated subjects - the frontline regulators and inspectors. This approach also requires an increased focus on the skills and training - and, where necessary, explicit codification - of the discretionary space within which they operate (Russell \& Hodges, 2019).

This pragmatic turn in statutory and government-led regulation, and the debates on it in the regulatory literature, holds promise to inform and advance JEPP debates on policy pragmatism, the discretionary space of those involved in environmental policy delivery, and the challenges of realising policy goals in complex multiactor contexts (e.g. Kythreotis, 2017; Togerson, 2018).

\section{A utilitarian turn}

In the 1980s, there was a call on governments to become more cost-effective and efficient - the turn to new public management (Hood, 1995; McLaughlin et al., 2002). Inspired by innovations within the business sector, governments began to experiment with risk assessment and risk management tools. These new instruments of risk modulation allowed governments to employ a utilitarian approach to 'allocate regulatory resources in proportion to the risks and interventions they require' (Davies et al., 2010, p. 963) and 'explicitly explain their selective decisions based on the assessment of the risk that the regulated actors (companies or individuals) present' (Macenaite, 2017, p. 512). In risk-based regulation, the focus is on the allocation of resources based on risk levels (Macenaite, 2017). These tools allowed governments to estimate risk by combining the chance of harm occurring with the impact of that harm. There are many methods to such estimation, and governments around the globe apply individual approaches with varying levels of success (IRGC, 2005; Rosa et al., 2014). In short, in this specific approach to risk-based regulation, risk is now often used as a decision-making resource that allows for a reasoned regulatory response to possible harm or gain (Baldwin \& Black, 2016). 
Moving away from the utilitarian turn in regulation for a brief moment, a different reading of the literature on risk-regulation considers the changing nature and understanding of risk. By the end of the twentieth century, writings by a range of influential thinkers on the role of risk in modern society entered the mainstream debate in the wake of large environmental disasters. While the details of their arguments differ considerably, their main lines of thought show striking similarities: In current times, people have become preoccupied with risk and taming the future, and despite all the controls that have been put in place to reduce, pool, mitigate or prevent risk, risk causes anxiety at the societal level (e.g. Beck, 1992; Giddens, 1997). The notions of new risks (and amplified existing ones), as well as the notions of systemic risks, raised by these thinkers echo particularly in the risk governance models we see around the globe today. New technologies, such as genetically modified foodstuffs and new forms of mining fossil fuels, are considered to bring huge opportunities, but they also come with environmental risks that cannot be objectively estimated (Giorgi, 2013; Hodge et al., 2014). At the same time, many of today's major risks, such as climate change, are systemic, meaning that they are embedded in the larger context of societal processes. 'Systemic risks have therefore a growing potential of harm since effects can be amplified or attenuated throughout the prolongation of effects based on a complex system of interdependencies' (van Asselt \& Renn, 2011, p. 436). This changed understanding of risk, so argue these scholars, has resulted in increased calls on governments to prevent harm to occur in the first place, rather than restore damage after it has occurred, or merely penalise those who violated the rules. In response, government-led regulation has shifted away further still from a 'reactive' stance towards an 'anticipatory,' 'precautionary' orientation (Assmuth et al., 2010; Hood et al., 2001).

Another utilitarian turn discussed in the broader regulatory literature is the increasing involvement of 'regulatory intermediaries' in a wide range of regulatory areas, including environmental regulation (Abbott et al., 2017). Since the 1990s, government regulators have increasingly turned to non-government organisations for support with the development, implementation and, sometimes, the enforcement of statutory and other forms of government-led regulation. This gives government regulators access to skills, knowledge, and other capacities they may not otherwise have readily available. In a similar vein, government regulators around the globe are increasingly adopting private standards and rules in statutory and other forms of governmentled regulation. For example, several local governments in the U.S. have adopted energy efficiency building codes developed in the private certification programme LEED (Leadership in Energy and Environmental Design). Other municipalities have gone less far but consider compliance with voluntary LEED requirements as equivalent to compliance with their local mandatory building codes (Van der Heijden, 2015). Whilst this involvement of non-government organisations and the adopting or recognition of non-government developed rules may provide governments with cost-effective regulatory solutions, it also raises questions about accountability, transparency, and possible conflicts of interest (Van der Heijden, 2017). It remains to be seen whether for-profit organisations ultimately feel a similar sense of responsibility for achieving the positive outcomes of environmental regulation as governments do.

This utilitarian turn in statutory and government-led regulation, and the attendant discussions within the regulatory literature, hold promise to inform and advance JEPP debates on risk politics, private governance for public environmental goods, and new public environmental management (e.g. Dreyer et al., 2014; Lange et al., 2013).

\section{A behavioural turn}

Statutory and other forms of government-led regulation, like many areas of policymaking and implementation, have long followed an understanding of human behaviour as conceptualised in rational choice theory (Baldwin et al., 2012; Halpern, 2019). This theory is predicated on the assumption that when people are faced with a choice from a variety of alternatives, they choose the alternative that has the highest worth or value to them. Insights from behavioural economics, cognitive sciences, and psychology have, however, pointed out that humans often deviate from this utility model, simply because they are less rational in making choices under uncertainty than is predicted by neoclassical economics (Kahneman, 2011; Simon, 1945; Thaler \& Sunstein, 2009). Building on these insights, scholars from the behavioural sciences have identified several patterns of 
behaviour that characterise the way people make decisions and how people deviate in predictable ways from neoclassical assumptions of rationality. Their work indicates that we rely on cognitive biases and heuristics ('mental shortcuts') when making choices, and shows that this sometimes results in suboptimal outcomes. (the full set of biases and heuristics uncovered over the last decades is too vast to discuss here but for an easily digestible overview, see McRaney, 2012, 2014)

As a result, since the early 2000s governments around the world have started to embrace a more realistic human behaviour model in the development and implementation of regulatory interventions - including the widely popular 'nudging' but also other uses of behavioural insights (OECD, 2017a). This move towards behavioural insights-informed regulation is sometimes heralded as the most promising shift in regulatory governance for its potential to effectively address environmental harms, including climate change (Halpern, 2019; OECD, 2017b). Advocates point to the example of modifiable behaviours such as energy consumption for domestic and commercial buildings and urban transportation. These categories account for 40-70 per cent of the energy consumed at the city level (De Almeida et al., 2011). A considerable amount is wasted, however, because of poor behavioural choices: rather than switching appliances fully off, people opt for the default standby power option (Rusk et al., 2011); rather than choosing novel energy-efficient construction processes, developers continue to rely on the energy-intensive approaches they are accustomed to (Martek et al., 2019); and rather than opting for ridesharing or carpooling, commuters stick to using their own cars (Nneoh et al., 2017).

Insights from the behavioural sciences may help to make environmental regulation more effective (Baldwin, 2014; Thaler \& Sunstein, 2009). For example, the presentation of regulatory options matters in achieving compliance. A classic study in the field sought to understand whether different ways of presenting a regulatory requirement would affect compliance with that requirement (Cialdini et al., 2006). The requirement prohibited visitors of Arizona's Petrified Forest National Park to take petrified wood from the park. When a sign was posted stating, 'Please don't remove the petrified wood from the park,' less than two percent of woodchips placed near the signs by the researchers were stolen. When the sign stated, 'Many past visitors have removed the petrified wood from the park, changing the state of the Petrified Forest,' eight percent of woodchips were stolen. The first sign stated in clear language what is expected and does so as an injunctive norm - it stated the rule and how one is expected to behave. The second sign is less clear but, more problematically, it gives a descriptive norm about what the general behaviour in the park is - that is, it is common for people to take woodchips. Framed differently, stealing woodchips sound like the norm rather than the exception and, thus, inadvertently normalised the behaviour it intended to stop. This single example indicates the essence of applying behavioural insights to environmental regulation: non-intrusive and often low-cost changes to environmental regulation may have a significant impact on compliance.

This behavioural turn in statutory and government-led regulation and the debates on it in the regulatory literature hold promise to inform and advance JEPP debates on behavioural science informed environmental policies, human behaviour and climate change, and biases in climate policy (e.g. Peters et al., 2017; Wolff et al., 2017).

\section{Conclusion: JEPP research on environmental regulation in the twenty-first century}

This article has explored whether, how, and with what results authors publishing in JEPP have engaged with statutory and other forms of government-led environmental regulation to achieve environmental goals. When setting out to research over 20 years of JEPP scholarship for this article, I had expected to find modest interest in the 'traditional' approach to environmental regulation and modest engagement with the regulatory literature on the pages of JEPP. Given the reality of the dominance of environmental regulation in real-world environmental policy and practice (see the introduction to the article), I was, however, surprised by the findings of the review presented here: statutory and other forms of government-led environmental regulation as a means to achieve the goals of environmental policy and planning appears an under-explored topic on the pages of JEPP. ${ }^{8}$ I would, therefore, like to urge the next two decades of JEPP scholarship to engage more closely with developments in statutory and other forms of government-led environmental regulation. I 
would also like to urge JEPP scholarship to engage more closely with the broader (socio-legal) regulatory literature and the debates central to it.

A first avenue of fruitful research in JEPP would be to engage more deeply with traditional forms of regulation. This is a call to be less attracted to yet another niche-innovation of environmental governance applied in a micro-setting and, instead, focus on 'less sexy' but large-scale 'traditional' regulatory interventions that affect large populations or sectors. A modest improvement to a conventional regulatory intervention in a large population may have greater impact than a high-end experimental governance intervention that addresses a marginal group of leaders. Other relevant questions to ask are: Why are traditional forms of regulation still dominant in environmental policy and planning around the world? What, if any, incremental or substantial changes to 'traditional' environmental regulation may have the largest accumulated effects?

A second avenue of fruitful research would be to engage more deeply with a selection of foundational texts in socio-legal regulatory scholarship. For example, the pragmatic, utilitarian, and behavioural turns to regulation and regulatory enforcement are discussed in books such as Nudge (Thaler \& Sunstein, 2009), Responsive Regulation (Ayres \& Braithwaite, 1992), The Government of Risk (Hood et al., 2001), and Smart Regulation (Gunningham \& Grabosky, 1998). Deeper engagement with regulatory scholarship in JEPP studies may help us better understand why environmental policy and planning programmes do not achieve their desired effects, and how future implementation may be improved. Besides, this part of the regulatory literature may provide useful evidence upon which environmental policymakers and planners can base new policies, as well as for scholars involved in 'living labs' who may wish to explore the use of innovative regulatory interventions in their jurisdictions. Comparative research of the performance of such interventions may help us better illuminate which forms of environmental regulation work; where they work best and why; and to what extent lessons can be drawn across policy problems and geographies.

A third avenue to explore are the normative, functional, operational similarities and differences of environmental regulation, and their impacts on its performance when applied to different parts of society. Statutory and other forms of government-led regulation have developed as an effective, albeit not always efficient, means to steer the behaviour of individuals and collectives towards desirable ends. The complex, wicked environmental problems we face today ask for large-scale behavioural change. Such large scale change is likely only to be achieved if ambitions, interests, and incentives in different parts of society are structurally coupled in new ways (Luhmann, 2004). For example, cap-and-trade regulation allows for the structural coupling of the ambitions of environmental policy (i.e. reduce carbon emission), economic interests (i.e. establish the value of carbon emissions), law (i.e. establishing the ownership of carbon emissions), and the behaviour of individuals and collectives (i.e. reduce the carbon emissions they own, or sell the carbon credits they own, as that comes with the highest economic gain or the lowest economic cost). What structural couplings in regulatory interventions are promising and how to achieve them are among the most pressing questions to address in the critical decades that lie ahead.

A fourth and, for this article, final avenue to suggest is to explore the interplay between statutory and government-led regulation and other environmental policy and planning instruments. A first trajectory here is to map, explore, and critique how 'mandatory' and 'voluntary' instruments complement each other, and what 'blend' of such instruments achieve the most desirable results in environmental policy mixes. A second trajectory is to explore the regulatory challenges resulting from the transnational and sometimes global nature of environmental risks. Statutory and other forms of government-led environmental regulation have a limited geographical reach - they are limited to the jurisdiction to which they apply. Yet the global flows of production, consumption, and even migration are causing huge environmental impacts across the world, often beyond what governments can regulate in their own jurisdiction. Truly pressing questions then arise about how governments can collaborate internationally (with other governments, but also non-government and for-profit organisations) to harmonise environmental regulation, to close gaps in environmental regulation, and to regulate and monitor the exporting and importing of each other's environmental risks and harms.

These are but four avenues that JEPP authors - and of course, JEPP editors - may wish to traverse in the future to build upon and expand regulatory scholarship. Recall, in this article I have mainly engaged with the development, implementation and enforcement of regulation as discussed in socio-legal scholarship. The 
regulatory literature is much broader (as also explained by Lo et al. elsewhere in this special issue) and future JEPP authors are strongly recommended to also explore other strands of regulatory scholarship - such as law and policy, the economics of regulation, or the politics of regulation - and engage more deeply with this literature and the debates central to it.

\section{Notes}

1. All volumes have been included in the review up until Volume 21, Issue 6. Book review articles published in JEPP have been left outside the scope of this systematic review. 'Online first' articles have been excluded from the review also.

2. Regular editorials are here understood as editorials and introductions to JEPP issues by the editors of the journal. Editorials and introductions to special issues as well as editorial and introductions to regular issues by guest editors are included in the 556 regular JEPP articles explored.

3. The term 'compliance' gave the same results as 'compli*' and no results were found for 'comply'.

4. The column 'Mentioned as keyword OR in title on $n$ JEPP article(s)' in table 1 adds up to 32 for terms indicating a possible regulatory focus. Because some articles use multiple keywords indicating a possible regulatory focus or multiple words in their titles, this represents only 21 unique articles.

5. It should be noted that this is by no means a full overview of foundational texts central to the field of regulatory scholarship.

6. A review of how JEPP scholarship has engaged with non-statutory forms of environmental regulation would, of course, make for an excellent research topic as well. Space limits me, unfortunately, to carry it out in this article as well.

7. The three turns in regulation discussed in what follows feature regularly on the pages of the top 15 journals for socio-legal regulatory scholarship (journals that all rank highly in the combined ISI Journal Citation Reports Ranking categories law, political science and public administration): Regulation and Governance, the Journal of Public Administration, Research and Theory (JPART), Law and Policy, Public Administration, Governance, the Journal of Policy Analysis and Management, Public Administration Review, Public Management Review, the Policy Studies Journal, Policy Sciences, Politics and Society, Administrative Science Quarterly, Social and Legal Studies, the Journal of Law and Society, and the International Journal of Law in Context. Readers interested in other turns in and forms of 'modern' (environmental) regulation (such as transnational regulation, collaborative regulation, dynamic regulation, experimental regulation, and regulatory stewardship) are strongly recommended to consult these journals. Readers interested in a 'law and economics' understanding of regulation or the 'economics of regulation' are advised to consult journals such as the Journal of Law and Economics, the International Review of Law and Economics, the Journal of Economic Theory, or the Journal of Regulatory Economics.

8. I should stress, once more, that non-statutory and sometimes non-government-led 'regulatory' interventions such as industry environmental self-regulation, voluntary environmental agreements, and environmental regulatory partnerships have been explored on the pages of JEPP.

\section{Acknowledgements}

The author wishes to thank the New Zealand Government Regulatory Practice Initiative (G-REG) for financial support. Many thanks also to the anonymous reviewers for their excellent feedback on an earlier draft of this article.

\section{Disclosure statement}

No potential conflict of interest was reported by the author(s).

\section{Funding}

This work was supported by New Zealand Government Regulatory Practice Initiative (G-REG).

\section{Notes on contributor}

Jeroen van der Heijden is Professor of Public Governance and Chair in Regulatory Practice at the School of Government, Victoria University (New Zealand) and Honorary Professor at the School of Regulation and Global Governance, Australian National University (Australia). His research is concerned with innovations in urban climate governance in the Global North and Global South. 


\section{ORCID}

Jeroen van der Heijden (D) http://orcid.org/0000-0001-6188-0556

\section{References}

Abbott, K. W., Levi-Faur, D., \& Snidal, D. (2017). Introducing regulatory intermediaries. The ANNALS of the American Academy of Political and Social Science, 670(1), 6-13. https://doi.org/10.1177/0002716217695519

Andrews, D. A., \& Bonta, J. (2010). Rehabilitating criminal justice and practice. Psychology, Public Policy, and Law, 16(1), 39-55. https://doi.org/10.1037/a0018362

Assmuth, T., Hildén, M., \& Benighaus, C. (2010). Integrated risk assessment and risk governance as socio-political phenomena: A synthetic view of the challenges. Science of the Total Environment, 408(18), 3943-3953. https://doi.org/10.1016/j.scitotenv.2009. 11.034

Ayres, I., \& Braithwaite, J. (1992). Responsive regulation. Oxford University Press.

Bailey, I. (2008). Industry environmental agreements and climate policy. JEPP, 10(2), 153-173. https://doi.org/10.1080/ 15239080801928410.

Baldwin, R. (2014). From regulation to behaviour change: Giving nudge the third degree. The Modern Law Review, 77(6), 831-857. https://doi.org/10.1111/1468-2230.12094

Baldwin, R., \& Black, J. (2016). Driving priorities in risk-based regulation: What's the Problem?. Journal of Law and Society, 43(4), 565-595. https://doi.org/10.1111/jols.12003

Baldwin, R., \& Cave, M. (1999). Understanding regulation. Oxford University Press.

Baldwin, R., Cave, M., \& Lodge, M. (2012). Understanding regulation - Second edition. Oxford University Press.

Balleisen, E. J., \& Moss, D. (2012). Government and markets. Cambridge University Press.

Bardach, E., \& Kagan, R. A. (1982). Going by the book. Temple University Press.

Bearfield, D. A., \& Eller, W. S. (2008). Writing a literature review. In K. Yang \& G. J. Miller (Eds.), Handbook of research methods in public administration - 2nd edition (pp. 61-72). Taylor \& Francis Group.

Beck, U. (1992). Risk society. Towards a new modernity. Sage Publications.

Blackman, A., Li, Z., \& Liu, A. (2018). Efficacy of command-and-control and market-based environmental regulation in developing countries. Annual Review of Resource Economics, 10(1), 381-404. https://doi.org/10.1146/annurev-resource-100517-023144

Bourdieu, P. (1987). The force of law. Hastings Law Journal, 38(5), 814-853.

Braathen, N. A. (2019). Flexibility mechanisms in environmental regulations. OECD.

Braithwaite, J. (2011). The essence of responsive regulation. University of British Columbia Law Review, 44(3), 475-520.

Braithwaite, J., \& Drahos, P. (2000). Global business regulation. Cambridge University Press.

Bulkeley, H., Castán Broto, V., Hodson, M., \& Marvin, S. (Eds.). (2013). Cities and low carbon transitions. Routledge.

Carter, D., \& Weible, C. (2013). Assessing rule compliance and robustness in recreational resource management. JEPP, 16(1), 117139. https://doi.org/10.1080/1523908X.2013.821943.

Cialdini, R., Demaine, L., Sagarin, B., Barrett, D., Rhoads, K., \& Winter, P. (2006). Managing social norms for persuasive impact. Social Influence, 1(1), 3-15. https://doi.org/10.1080/15534510500181459

Daniels, T. (Ed.). (2014). Environmental planning handbook. Routledge.

David, M., \& Sinclair-Desgagné, B. (2005). Environmental regulation and the eco-industry. Journal of Regulatory Economics, 28(2), 141-155. https://doi.org/10.1007/s11149-005-3106-8

Davies, G. J., Kendall, G., Soane, E., Li, J., Charnley, F., \& Pollard, S. J. T. (2010). Regulators as 'agents': Power and personality in risk regulation and a role for agent-based simulation. Journal of Risk Research, 13(8), 961-982. https://doi.org/10.1080/13669877. 2010.486075

De Almeida, A., Fonseca, P., Schlomann, B., \& Feilberg, N. (2011). Characterization of the household electricity consumption in the EU, potential energy savings and specific policy recommendations. Energy and Buildings, 43(8), 1884-1894. https://doi.org/10. 1016/j.enbuild.2011.03.027

Decker, C. (2015). Modern economic regulation. Cambridge University Press.

Drahos, P. (Ed.). (2017). Regulatory theory. ANU Press.

Dreyer, M., Bostrom, M., \& Jonsson, A. M. (2014). Participatory deliberation, risk governance and management of the marine region in the European Union. JEPP, 16(4), 497-511. https://doi.org/10.1080/1523908X.2013.866891.

Dudley, S. E., \& Brito, J. (2012). Regulation. Nervatus Center/The George Washington University Regulatory Studies Center.

Fairman, R., \& Yapp, C. (2005). Enforced self-regulation, prescription, and conceptions of compliance within small usinesses: The impact of enforcement. Law and Policy, 27(4), 491-519. https://doi.org/10.1111/j.1467-9930.2005.00209.x

Falkner, R. (2013). The handbook of global climate and environment policy. John Wiley \& Sons.

Giddens, A. (1997). Sociology. Polity Press.

Giorgi, L. (2013). The pitfalls of European risk governance. Innovation, 26(4), 365-375. https://doi.org/10.1080/13511610.2013. 776948. 
Gunningham, N. (2002). Regulating small and medium sized enterprises. Journal of Environmental Law, 14(1), 3-32. https://doi. org/10.1093/jel/14.1.3

Gunningham, N. (2009). Environment Law, regulation and governance: Shifting Architectures. Journal of Environmental Law, 21 (2), 179-212. https://doi.org/10.1093/jel/eqp011

Gunningham, N., \& Grabosky, P. (1998). Smart regulation. Oxford University Press.

Halpern, D. (2019). Inside the nudge unit. Penguin.

Hodge, G. A., Maynard, A., \& Bowman, D. (2014). Nanotechnology: Rhetoric, risk and regulation. Science and Public Policy, 41(1), 1-14. https://doi.org/10.1093/scipol/sct029

Hood, C. (1995). The "new public management" in the 1980s: Variations on a theme. Accounting, Organizations and Society, 20(23), 93-109. https://doi.org/10.1016/0361-3682(93)E0001-W

Hood, C., Rothstein, H., \& Baldwin, R. (2001). The government of risk. Oxford University Press.

Howlett, M., \& del Rio, P. (2015). The parameters of policy portfolios: Verticality and horizontality in design spaces and their consequences for policy mix formulation. Environment and Planning C: Government and Policy, 33(5), 1233-1245. https://doi.org/ 10.1177/0263774X15610059

International Risk Governance Council (IRGC). (2005). Risk governance. International Risk Governance Council.

Jordana, J., \& Levi-Faur, D. (2004). The politics of regulation. Edward Elgar Publishing.

Jordan, A., Wurzel, R., \& Zito, A. (2003). 'New' instruments of environmental governance: Patterns and Pathways of change. Environmental Politics, 12(1), 1-24. https://doi.org/10.1080/714000665

Jordan, A., Wurzel, R., \& Zito, A. (2005). The rise of 'new' policy instruments in comparative perspective: Has governance eclipsed government?. Political Studies, 53(3), 477-496. https://doi.org/10.1111/j.1467-9248.2005.00540.x

Jordan, A., Wurzel, R., \& Zito, A. (2013). Still the century of 'new' environmental policy instruments? Exploring patterns of innovation and continuity Environmental Politics, 22(1), 155-173. https://doi.org/10.1080/09644016.2013.755839

Kahn, A. (1988). The economics of regulation. Massachusetts Institute of Technology.

Kahneman, D. (2011). Thinking fast and slow. Farrar, Straus and Giroux.

Kythreotis, A. (2017). Rethinking climate change research. JEPP, 17(1), 148-151. https://doi.org/10.1080/1523908X.2014.891344.

Lange, P., Driesesen, P., Sauer, A., Bornemann, B., \& Burger, P. (2013). Governing towards sustainability. JEPP, 15(3), 403-425. https://doi.org/10.1080/1523908X.2013.769414.

Levi-Faur, D. (2011). Handbook on the politics of regulation. Edward Elgar.

Lipsky, M. (1980). Street-level bureaucracy. Russell Sage Foundation.

Lodge, M., \& Wegrich, K. (2012). Managing regulation. Palgrave Macmillan.

Luhmann, N. (2004). Law as a social system. Oxford University Press.

Macenaite, M. (2017). The "riskification" of European data protection law through a two-fold shift. European Journal of Risk Regulation, 8(3), 506-540. https://doi.org/10.1017/err.2017.40

Majone, G. (2016). The evolution of the regulatory state. In A. Burgess, A. Alemanno, \& J. O. Zinn (Eds.), Routledge handbook of risk studies (pp. 2016-2228). Routledge.

Martek, I., Hosseini, R., Shrestha, A., Edwards, D., \& Durdyev, S. (2019). Barriers inhibiting the transition to sustainability within the Australian construction industry: An investigation of technical and social interactions. Journal of Cleaner Production, 211 (February), 281-292. https://doi.org/10.1016/j.jclepro.2018.11.166

May, P. (2007). Regulatory regimes and accountability. Regulation \& Governance, 1(1), 8-26. https://doi.org/10.1111/j.1748-5991. 2007.00002.x

May, P., \& Winter, S. (1999). Regulatory enforcement and compliance: Examining Danish agro-environmental policy. Journal of Policy Analysis and Management, 18(4), 625-651. https://doi.org/10.1002/(SICI)1520-6688(199923)18:43.0.CO;2-U

Mayer, B., Brown, P., \& Linder, M. (2002). Moving further upstream: From toxics reduction to the precautionary principle. Public Health Reports, 117(6), 574-586. https://doi.org/10.1016/S0033-3549(04)50202-9

McCraw, T. K. (1984). Prophets of regulation. Mass.: Harvard University Press.

McLaughlin, K., Osborne, S., \& Ferlie, E. (2002). New public management. New York: Routledge.

McRaney, D. (2012). You are not so smart. Gotham Books.

McRaney, D. (2014). You are now less dumb. Gotham Books.

Morgan, B., \& Yeung, K. (2007). An introduction to law and regulation. Cambridge University Press.

Nneoh, J. G., Chipulu, M., \& Marshall, A. (2017). What encourages people to carpool? An evaluation of factors with meta-analysis. Transportation, 44(2), 423-447. https://doi.org/10.1007/s11116-015-9661-7

OECD. (2017a). Behavioural insights and public policy.

OECD. (2017b). Tackling environmental problems with the help of behavioural insights.

Osborne, D., \& Gaebler, T. (1992). Reinventing government. Reading.

Parker, C. (2000). Reinventing regulation within the corporation. Administration \& Society, 32(5), 529-565. https://doi.org/10. 1177/00953990022019579

Parker, C. (2013). Twenty years of responsive regulation: An appreciation and appraisal. Regulation \& Governance, 7(1), $2-13$. https://doi.org/10.1111/rego.12006

Parker, C., Scott, C., Lacey, N., \& Braithwaite, J. (2005). Regulating law. Oxford University Press. 
Percival, R., Schroeder, R., Miller, A., \& Leape, J. (2018). Environmental regulation. Wolters Kluwers.

Perdan, S., \& Azapagic, A. (2011). Carbon trading: Current schemes and future developments. Energy Policy, 39(10), 6040-6054. https://doi.org/10.1016/j.enpol.2011.07.003

Peters, B. G., Jordan, A., \& Tosun, J. (2017). Over-reaction and under-reaction in climate policys. JEPP, 19(6), 612-624. https://doi. org/10.1080/1523908X.2017.1348225.

Power, M. (1999). The audit society. Oxford University Press.

Rosa, E., Renn, O., \& McCright, A. (2014). The risk society revisited. Temple University Press.

Rusk, B., Mahfouz, T., \& Jones, J. (2011). Electricity's “disappearing act”. Technological Directions, 71(1), 22-25.

Russell, G., \& Hodges, C. (2019). Regulatory delivery. Hart Publishing.

Scott, C. (2012). Regulatory governance and the challenge of constitutionalism. In D. Oliver, T. Prosser, \& R. Rawlings (Eds.), The regulatory state (pp. 15-33). Oxford University Press.

Shapiro, S. A., \& Glicksman, R. L. (2003). Risk regulation at risk. Stanford University Press.

Simon, H. A. (1945). Administrative behavior. Free Press.

Sparrow, M. K. (2000). The regulatory craft. Brookings Institution.

Stigler, G. J. (1971). The theory of economic regulation. The Bell Journal of Economics and Management Science, 2(Spring), 3-21. https://doi.org/10.2307/3003160

Sutton, A., Papaioannou, D., \& Booth, A. (2016). Systematic approaches to a successful literature review. Sage.

Taylor, B., \& Lawrence, G. (2012). Agri-political organizations in environmental governance. JEPP, 14(4), 337-359. https://doi.org/ 10.1080/1523908X.2012.714565.

Thaler, R., \& Sunstein, C. (2009). Nudge - revised edition. Penguin.

Togerson, D. (2018). Reflexivity and developmental constructs. JEPP, 20(6), 781-791. https://doi.org/10.1080/1523908X.2013. 817949.

Tyler, T. R. (1990). Why people obey the law. Yale University Press.

van Asselt, M., \& Renn, O. (2011). Risk governance. Journal of Risk Research, 14(4), 431-449. https://doi.org/10.1080/13669877. 2011.553730

Van der Heijden, J. (2015). On the potential of voluntary environmental programmes for the built environment: A critical analysis of LEED. Journal of Housing and the Built Environment, 30(4), 553-567. https://doi.org/10.1007/s10901-014-9428-Z

Van der Heijden, J. (2017). Brighter and darker sides of intermediation. The ANNALS of the American Academy of Political and Social Science, 670(1), 207-224. https://doi.org/10.1177/0002716217693583

Viscusi, W. K., Harrington, J. E., \& Vernon, J. (2005). Economics of regulation and antitrust. MIT Press.

Voermans, W. (2016). Legislation and regulation. In U. Karpen, H. Xanthaki, \& L. Mader (Eds.), Legislation in Europe (pp. 17-32). Hart Publishing.

Vogel, D. (2012). The politics of precaution. Princeton University Press.

Vogel, S. K. (1996). Freer markets, more rules. Cornell University Press.

Weiss, J., Stephan, A., \& Anisimova, T. (2019). Well-designed environmental regulation and firm performance: Swedish evidence on the Porter hypothesis and the effect of regulatory time strategies. Journal of Environmental Planning and Management, 62(2), 342-363. https://doi.org/10.1080/09640568.2017.1419940

Wilson, J. Q. (1989). Bureaucracy. Basic Books.

Wolff, F., Schonherr, N., \& Heyen, D. A. (2017). Effects and success factors of sustainable consumption policy instruments. JEPP, 19 (4), 457-472. https://doi.org/10.1080/1523908X.2016.1254035.

Young, O., King, L., \& Schroeder, H. (Eds.). (2008). Institutions and environmental change. MIT Press. 